\title{
Effect of Blended Learning on Newly Nursing Student's Outcomes Regarding New Trends in Nursing Subject at Ain Shams University
}

\author{
Fathia Ahmed Mersal ${ }^{1, *}$, Nahed Ahmed Mersal ${ }^{2}$ \\ ${ }^{1}$ Assisst. Prof. of Community Health Nursing, Faculty of Nursing, Ain Shams University \\ ${ }^{2}$ Assisst. Prof. of Medical Surgical Nursing, Faculty of Nursing, Ain Shams University \\ *Corresponding author: khomarkh@yahoo.com
}

Received October 17, 2014; Revised October 27, 2014; Accepted November 03, 2014

\begin{abstract}
Blended learning refers to a method of instruction that utilizes two or more complementary approaches to teach the same material. By combining classroom lectures, activities, discussions, and/or web-based modules. Aim: Examine the effect of blended learning on newly nursing student's outcomes regarding new trends in nursing subject at Ain Shams University. Hypothesis: The Students who will be exposed to blended learning (Study group) will have improved Outcomes compared to the Students in the control group who will be exposed to lecture regarding new trends in nursing subject. Design: A quasi experimental study design was utilized to accomplish the aim of this study. Setting: Faculty of Nursing Ain Shams University Cairo Egypt. Sample: Two purposive samples of all available first year students' from the previously mentioned study setting in 2012/2013 and 2013/2014 academic years as control group and study group respectively. Students were included in this study were from both gender, and willing to participate in the study. Tools for data collection: A self-administered structured questionnaire to assess demographic characteristics and learning needs, student's satisfaction questionnaire sheet, student's academic achievement sheet. Results: There was improvement regarding satisfactory level of achievement and decrease in the percent of poor and very poor of blended learning group with no statistical difference between two groups. There was improvement in student's satisfaction of blended learning group regarding the course and teaching method with highly statistical significant difference between two groups. Conclusions: blended learning improved newly nursing student's Outcomes both academic achievement and student's satisfaction than lecture regarding new trends in nursing subject at Ain Shams University. Recommendations: blended learning can be used to facilitate nursing education, more researches done to determine durability rate of the information of this methods.
\end{abstract}

Keywords: blended learning, newly nursing students, student's outcomes

Cite This Article: Fathia AhmedMersal, and Nahed Ahmed Mersal, "Effect of Blended Learning on Newly Nursing Student's Outcomes Regarding New Trends in Nursing Subject at Ain Shams University.” American Journal of Educational Research, vol. 2, no. 11 (2014): 1036-1043. doi: 10.12691/education-2-11-6.

\section{Introduction}

Nursing educators continually seek effective teaching strategies to enhance student's learning and promote the ability to problem solving [1]. The Internet technologies are one of the fastest growing and the most penetrated technologies in the world [2]. In more recent years nursing education is rapidly advancing the use of technology such as e-learning in both the clinical simulation and theoretical courses [3].

The newly nursing students are subjected to different kinds of stressors the main sources of stress are linking them to clinical, academic, social and interpersonal areas [4]. Students entering university from secondary schools have lacking confidence in themselves and often need to be encouraged to learn how to learn. Teaching strategies reflect the diverse nature of the student population and prepare nursing students with the knowledge to be safe, competent, beginning practitioners who are 'work ready' [5].

Concern for using alternate teaching-learning methods arise when considering the complexity of nursing education, the need to respond to a continuously changing health care environment, and the need to ensure safe and effective patient care [6,7].

According to Bodie et al. [8] blended learning refers to a method of instruction that utilizes two or more complementary approaches to teach the same material. By combining classroom lectures, activities, discussions, and/or web-based modules. Ruiz et al. [9] argued that learners would benefit more from a blended learning model, which incorporates traditional style classroom lectures with e-learning element than from a sudden switch to e-learning.

Blended learning is becoming an increasingly popular form e-learning, particularly suitable for use in the process of transition from traditional forms of learning and 
teaching towards e-learning [10]. The application of blended learning strategies could be the direct cause of improved passing rate of examinations within a group of students [11]. Blended learning was believed to improve student learning by offering more interaction between teachers, students and technology and became a preferred model for course delivery $[12,13]$.

E-learning has many advantages, including increased accessibility to educational materials (at a time and place chosen by learners), personalized instruction (to tailor education to individual learners' needs), and standardization of content [14].

However, more criticisms voiced about e-learning are that learners need to have access to the internet and e-mail. Slow internet connections or older computers may make accessing the course materials difficult-this may cause the learners to get frustrated and give up [15]. Another criticism about e-learning is that students may feel isolated from the instructor. When instructors and other learners are not meeting face to face, it is possible to misinterpret what was meant [16].

Educators also offer curricula in combinative environments. This approach to learning is referred to as blended learning and is a combination of cyber and traditional environments. According to Allen et al [17] blended learning was believed to improve student learning by offering more interaction between teachers, students, and technology and became a preferred model for course delivery.

According to Dziuban et al [18] blended courses have the potential to increase student learning outcomes while the online courses lowering attrition rates and increased dropout rates in distance learning.

The retention of students in an online learning environment can sometimes be low. Also the noncompletion rates in an online learning is more than the traditional face-to-face environment [19]. This issue can lead to unsatisfied faculty and student learners. This will lead higher education institutions back to the drawing board to learn how to incorporate online learning environments as an effective learning tool [20].

Student satisfaction was shown to improve learner studies and contribute to retention. Dissatisfied learners can hardly do well in their studies, and this leads to poor performance. Educators should integrate variables affecting learner satisfaction to increase learner persistence. Research showed that learner satisfaction affected students' learning and led to learner completion $[21,22]$.

The benefits of engaging in a blended environment can assist in the acceptance of new technologies and enhance the experience of students [23]. Also engaging in this environment can support students in their application of information, communication and technologies. The need for students to engage in these technological platforms is vital. Supporting students in this is seen as helping gain lifelong skills which they may transfer into the workplace [24].

\subsection{Significance of the Study}

The main goals of nursing education are to equip students and graduate nurses with the necessary knowledge and skills and to provide them with the strategies for their application in practice. New and advancing technologies provide enormous opportunities for curriculum designers, teachers, students and patients to engage in exciting and innovative learning experiences. As with any educational intervention, care must be taken to ensure that the availability of technology enhances learning and is not just technology for technology's sake [25]. When used appropriately in education, interactive technological strategies have been identified as enriching student teaching [26].

Furthermore, is the effect of blended learning on student outcomes, and evidence supports the supposition that technology-enhanced teaching used in the fields of health and science positively influences students' learning outcomes $[27,28]$. Indeed, in a study of a blended learning course students had higher final grades compared to students studying the same course in a traditional manner [29]. Also, another group of students studying a cardiovascular element of a course demonstrated significant improvement in their performance after using the technological tools that were made available to them via a website [26]. Similar improvements in performance by both on-campus and distance-learning students undertaking e-learning anatomy courses suggests that this method can be used successfully to teach this subject [30,31].

\subsection{Aim}

The aim of this study was to examine the effect of blended learning on newly nursing student's outcomes both academic achievement and student's satisfaction regarding new trends in nursing subject at Ain Shams University.

\subsection{Hypothesis}

It was hypothesized that the Students who will be exposed to blended learning (Study group) will have improved Outcomes both academic achievement and student's satisfaction compared to the students in the control group who will be exposed to lecture regarding new trends in nursing subject.

\section{Subjects and Methods}

\subsection{Research Design}

A quasi experimental study design was utilized to accomplish the aim of this study.

\subsection{Setting}

The study was conducted in Faculty of Nursing Ain Shams University Cairo Egypt.

\subsection{Sample}

Two purposive samples of all available first year students' from the previously mentioned study setting in 2012/2013 and 2013/2014 academic years as control group and study group respectively. Control group exposed to traditional teaching method (Lecture) while the study group exposed to blended learning. Students were 
included in this study were from both gender, and willing to participate in the study.

\subsection{Tools for Data Collection}

Three different tools were used to collect data pertinent for this study. They included the following:

\subsubsection{Tool 1}

A self-administered structured questionnaire to assess demographic characteristics and learning needs, it was developed by researcher, The first part was concerned with characteristics of the students such as age, gender, residence place and studying this course before. The second part was concerned with learning needs assessment of the students such as language's skills difficulties, computer's skills difficulties internet's skills difficulties and method of teaching that preferred by students. Validation by a group of five experts at Faculty of Nursing, Ain Shams University was done. Testing reliability was done.

\subsubsection{Tool 2}

Student's satisfaction questionnaire sheet, it was developed by researcher, first part was concerned with: Student's satisfaction regarding learning of this course such as develop skills in career, develop knowledge, develop ability to solve problems, to criticize, to teamwork, to be self-independence to communicate opinions to others, analytical abilities, validity and reliability were done. Second part was concerned with student's satisfaction regarding method of teaching such as encouraged effective participation, enabled deep understanding of difficult concepts, contributed to keep time, develop ability to acquire knowledge, increased focus and interpretation of observation, increased ability to self-learning and increased ability to understand of the courses. It contain five categories; a strongly agree, agree, don't know, disagree, strongly disagree. Validation by a group of five experts in medical surgical nursing department at Faculty of Nursing, Ain Shams University was done. Testing reliability was done.

\subsubsection{Tool 3}

Academic achievement sheet. It was developed by researcher. Total scores are 100 marks, it contain five categories; excellent, very good, good, fair, poor and very poor. Final exam of New trends in nursing subject in 2012/2013 academic year was consisted of (50) MCQ questions with score (50) marks, (30) Essay question with score (30) marks and (20) Matching questions with score (20) marks. Also final exam of New trends in nursing subject in 2013/2014 academic year was consisted (50) MCQ questions with score (50) marks, (30) Essay question with score (30) marks and (20) Matching questions with score (20) marks. Validation by a group of five experts in medical surgical nursing department at Faculty of Nursing, Ain Shams University was done. Testing reliability was done.

\subsection{Pilot Study}

The pilot study was conducted on 10 students to test the clarity, feasibility and applicability of the determent tools.
Based on the result of the pilot study, no modifications were done. The students who included in the pilot study were included in study sample.

Procedures of the study: The current study was carried out on three phases, preparatory phase, implementation phase and evaluation phase.

\subsection{Phase I: Preparatory and Planning phase}

Head of Medical Surgical Nursing Department gave permission to perform the study. Confidentiality and Voluntary nature of participation from students was insured and purpose of the study was explained. The web sites were determined and CD was prepared by the researchers for the students who have not availability of net. CD was revised by a group of five expertise in medical surgical nursing department at faculty of nursing at Ain Shams University for the content validity. Based on the opinion of expertise suitable modifications were done and then the final forms were developed.

\subsection{Phase 2: Implementation Phase}

Assessment of demographic characteristics, learning needs, student's satisfaction regarding this course and student's satisfaction regarding method of teaching for the first year students in the 2012/2013 academic year (control group) then assessment of demographic characteristics, learning needs, student's satisfaction for the first year students in the 2013/2014 academic year (study group) before implementation of blended learning.

Implementation of blended learning was done through two main parts lecture and e-learning;

Lecture covered the knowledge level of the same content that taught to the control group (assertiveness, empowerment, decision making, critical thinking, concept of change, evidence based practice, nursing informatics, clinical pathway and professional standard in nursing practice. E-learning focused on analysis, synthesis and evaluation level of knowledge for the same content. Students were informed with web sites and CD was given to each student to use it in case of unavailability of net.

\subsection{Evaluation Phase}

The evaluation phase was emphasized on examine the effect of blended learning on newly nursing student's outcomes booth academic achievement and student's satisfaction regarding new trends in nursing subject at Ain Shams University in order to compare between the results pre, and post intervention to determine the level of improvement in student's outcomes

Statistical design: data entry and analysis were done using the Statistical Package for Social Science (SPSS) version 16. Data were presented in the tables and charts using actual numbers and percentages. Appropriate statistical methods were applied. Regarding $\mathrm{P}$ value, it was considered that: non-significant (NS) if $\mathrm{P}>0.05$, Significant (S) if $\mathrm{P}<0.05$, Highly Significant (HS) if $\mathrm{P}<$ 0.01 .

\section{Results}

The results of this study answered the research questions through three main parts; 
- Demographic characteristics and Learning needs of lecture and blended learning groups in the first part.

- Assessment of academic achievement and students' satisfaction of lecture and blended learning groups in the second part.
- Correlation between student's satisfaction and Demographic characteristics, learning needs and academic achievement of two groups.

Table 1. Demographic characteristics of lecture and blended learning groups

\begin{tabular}{|c|c|c|c|c|c|c|}
\hline \multirow{2}{*}{ Parameters } & \multicolumn{2}{|c|}{ Lecture group $N=(\mathbf{2 0 0})$} & \multicolumn{2}{|c|}{ blended learning group $n=(191)$} & \multirow{2}{*}{$X^{2}$} & \multirow{2}{*}{$P$ value } \\
\hline & No & $\%$ & No & $\%$ & & \\
\hline Mean and standard deviation of age & \multicolumn{2}{|c|}{$18 \pm 0.64$} & \multicolumn{2}{|c|}{$18.77 \pm 0.69$} & T-0.33- & 0.740 \\
\hline $\begin{array}{c}\text { Sex } \\
\text { Male } \\
\text { Female }\end{array}$ & $\begin{array}{c}58 \\
142\end{array}$ & $\begin{array}{l}29 \\
71\end{array}$ & $\begin{array}{c}48 \\
143\end{array}$ & $\begin{array}{l}25.1 \\
74.9\end{array}$ & 0.74 & 0.22 \\
\hline $\begin{array}{l}\text { Residence place } \\
\text { Urban } \\
\text { Rural }\end{array}$ & $\begin{array}{c}130 \\
70\end{array}$ & $\begin{array}{l}65 \\
35\end{array}$ & $\begin{array}{c}126 \\
65\end{array}$ & $\begin{array}{l}66 \\
34\end{array}$ & 0.041 & 0.46 \\
\hline $\begin{array}{c}\text { Studying course last year } \\
\text { Yes } \\
\text { No }\end{array}$ & $\begin{array}{c}54 \\
146\end{array}$ & $\begin{array}{l}27 \\
73\end{array}$ & $\begin{array}{c}58 \\
133\end{array}$ & $\begin{array}{l}30.4 \\
69.6\end{array}$ & 0.54 & 0.26 \\
\hline
\end{tabular}

Table 1 shows that mean age of students in both lecture and blended learning groups was $18 \pm 0.64$ and $18.77 \pm 0.69$ respectively, $71 \%$ and $74.9 \%$ of them were female, $65 \%$ and $66 \%$ of them of living in urban areas, $27 \%$ and $30.4 \%$ were studying this course in the last year. This table also shows that there were no statistical significant differences between two groups regarding demographic characteristics.

Table 2. Learning needs assessment of lecture and blended learning groups

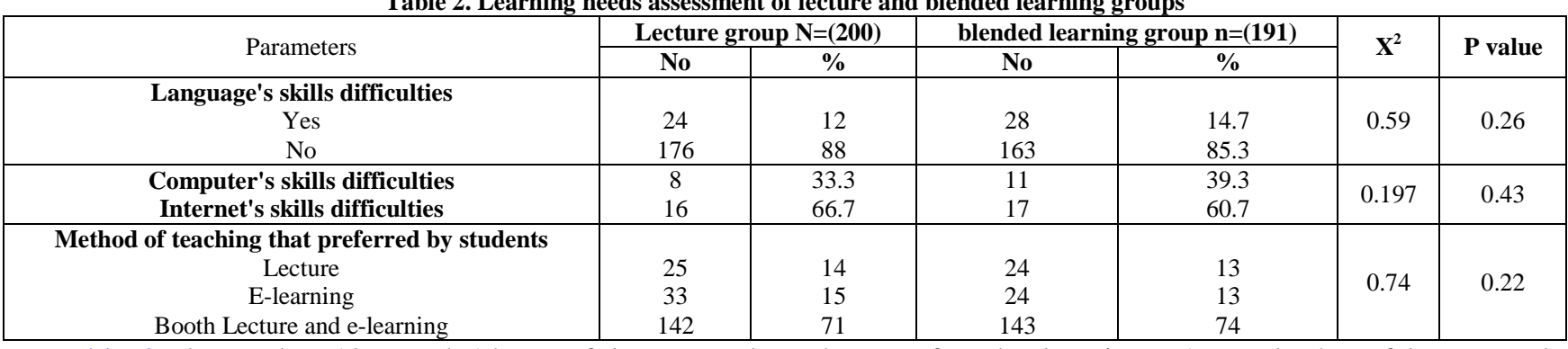

Table 2 shows that $12 \%$ and $14.7 \%$ of lecture and blended learning groups had Language's skills difficulties respectively, $33.3 \%$ and $39.3 \%$ of them had Computer's skills difficulties respectively, and $66.7 \%$ and $60.7 \%$ of them had Internet's skills difficulties respectively, 14\% and $13 \%$ of them preferred lecture while $15 \%$ and $13 \%$ of them preferred e-learning, $71 \%$ and $74 \%$ of lecture and blended learning groups preferred booth lecture and elearning together. There were no statistical significant differences between two groups regarding learning needs assessment.

Table 3. Academic Achievement assessment of lecture and blended learning groups

\begin{tabular}{|c|c|c|c|c|c|c|}
\hline \multirow{2}{*}{ Parameters } & \multicolumn{2}{|c|}{ Lecture group $\mathrm{N}=(201)$} & \multicolumn{2}{|c|}{ blended learning group $n=(242)$} & \multirow{2}{*}{$\mathrm{X} 2$} & \multirow{2}{*}{ P value } \\
\hline & No & $\%$ & No & $\%$ & & \\
\hline Academic Achievement Excellent to good & 107 & 53.2 & 127 & 52.5 & 2.92 & 0.22 \\
\hline Satisfactory & 47 & 23.4 & 71 & 29.3 & 2.92 & 0.22 \\
\hline Poor and Very poor & 47 & 23.4 & 44 & 18.2 & 2.92 & 0.22 \\
\hline
\end{tabular}

Regarding academic achievement, Table 3 shows that $53.2 \%$ and $52.5 \%$ of students in lecture and blended learning groups had excellent to good respectively, while there was improvement regarding satisfactory achievement whereas $23.4 \%$ and $29.3 \%$ of them had

satisfactory achievement respectively, also it shows that decrease in the percent of poor and very poor whereas $23.4 \%$ and $18.2 \%$ of them had poor and very poor respectively, with no statistical difference between two groups.

Table 4. Student's satisfaction regarding Learning of this course

\begin{tabular}{|c|c|c|c|c|c|c|}
\hline \multirow{2}{*}{ Course satisfaction } & \multicolumn{2}{|c|}{ Lecture group $\mathrm{N}=(200)$} & \multicolumn{2}{|c|}{ blended learning group $n=(191)$} & \multirow{2}{*}{ Test X2 } & \multirow{2}{*}{$\mathrm{P}$ value } \\
\hline & No & $\%$ & No & $\%$ & & \\
\hline Develop skills in career & 97 & 48.5 & 128 & 67 & 13.71 & 0.000 \\
\hline Developed ability to solve problems & 91 & 45.5 & 127 & 66.5 & 17.45 & 0.000 \\
\hline Developed ability to communicate opinions to others & 95 & 47.5 & 138 & 72.3 & 24.85 & 0.000 \\
\hline Develop analytical abilities & 67 & 33.5 & 98 & 51.3 & 12.70 & 0.000 \\
\hline Grown abilities to criticize & 94 & 47 & 112 & 58.6 & 5.30 & 0.014 \\
\hline Develop knowledge in a variety of topics & 95 & 47.5 & 146 & 76.4 & 34.60 & 0.000 \\
\hline Improve ability to teamwork. & 94 & 47 & 143 & 74.9 & 31.78 & 0.000 \\
\hline Develop ability to be self-independence & 67 & 33.5 & 137 & 71.7 & 57.21 & 0.000 \\
\hline
\end{tabular}

Regarding students' satisfaction Table 4 shows that less than half of lecture group was satisfied with learning for this course while more than half of blended learning group were satisfied with this course. This table also shows that highly statistical significant difference in most items between two groups regarding students' satisfaction with this course. 
Table 5. Student's satisfaction regarding method of teaching

\begin{tabular}{|c|c|c|c|c|c|c|}
\hline \multirow{2}{*}{ Teaching methods satisfaction } & \multicolumn{2}{|c|}{ Lecture group $\mathrm{N}=(200)$} & \multicolumn{2}{|c|}{ blended learning group $n=(191)$} & \multirow{2}{*}{ Test X2 } & \multirow{2}{*}{$P$ value } \\
\hline & No & $\%$ & No & $\%$ & & \\
\hline Encouraged effective participation. & 98 & 49 & 116 & 60.7 & 5.42 & 0.013 \\
\hline Enabled deep understanding of difficult concepts & 90 & 45 & 125 & 65.4 & 16.49 & 0.000 \\
\hline Contributed to keep time & 94 & 47 & 117 & 61.3 & 7.99 & 0.003 \\
\hline Develop ability to acquire knowledge & 67 & 33.5 & 144 & 75.4 & 69.01 & 0.000 \\
\hline Increased interpretation of knowledge & 97 & 48.5 & 127 & 66.5 & 12.92 & 0.000 \\
\hline Increased ability to self-learning & 93 & 46.5 & 136 & 71.2 & 24.57 & 0.000 \\
\hline Increased ability of understanding of the courses & 93 & 46.5 & 131 & 68.6 & 19.47 & 0.000 \\
\hline
\end{tabular}

Regarding student's satisfaction with teaching method,

Table 5 shows that less than half of a lecture group was satisfied with teaching method for this course while nearly two-thirds of blended learning group were satisfied with

teaching method for this course. This table also shows highly statistical significant difference in most items between two groups regarding student's satisfaction with teaching method for this course.

Table 6. Student satisfaction difference between lecture and blended learning groups

\begin{tabular}{|c|c|c|c|c|c|c|}
\hline \multirow{2}{*}{ Parameters } & \multicolumn{2}{|c|}{ Lecture group $\mathrm{N}=(200)$} & \multicolumn{2}{|c|}{ blended learning group $n=(191)$} & \multirow{2}{*}{ Test X2 } & \multirow{2}{*}{$\mathrm{P}$ value } \\
\hline & No & $\%$ & No & $\%$ & & \\
\hline \multicolumn{5}{|c|}{ student's satisfaction with learning of this course: } & \multirow{4}{*}{91.31} & \multirow{4}{*}{0.000} \\
\hline Satisfied & 22 & 11 & 108 & 56.5 & & \\
\hline Unsatisfied & 178 & 89 & 83 & 43.5 & & \\
\hline Mean and SD & \multicolumn{2}{|c|}{$11.74 \pm 2.71$} & \multicolumn{2}{|c|}{$14.81 \pm 3.84$} & & \\
\hline \multicolumn{5}{|c|}{ student's satisfaction with teaching method } & \multirow{4}{*}{50.61} & \multirow{4}{*}{0.000} \\
\hline Satisfied & 43 & 21.5 & 108 & 56.5 & & \\
\hline Unsatisfied & 157 & 78.5 & 83 & 43.5 & & \\
\hline Mean and SD & \multicolumn{2}{|c|}{$10.40 \pm 2.51$} & \multicolumn{2}{|c|}{$12.87 \pm 3.26$} & & \\
\hline \multicolumn{5}{|c|}{ Total student's satisfaction } & \multirow{4}{*}{65.81} & \multirow{4}{*}{0.000} \\
\hline Satisfied & 41 & 20.5 & 116 & 60.7 & & \\
\hline Unsatisfied & 159 & 79.5 & 75 & 39.3 & & \\
\hline Mean and SD & \multicolumn{2}{|c|}{$22.14 \pm 5.20$} & \multicolumn{2}{|c|}{$27.68 \pm 6.55$} & & \\
\hline
\end{tabular}

Table 6 shows that $11 \%$ and $56.5 \%$ of students in lecture and blended learning groups were satisfied regarding learning of this course, mean score $11.74 \pm 2.71$ and $14.81 \pm 3.84$ respectively. Regarding teaching method satisfaction, $21.5 \%$ and $56.5 \%$ of them were satisfied, mean score $10.40 \pm 2.51$ and $12.87 \pm 3.26$ respectively. Also this table shows that $20.5 \%$ and $60.7 \%$ of them were satisfied regarding total satisfaction of this course $22.14 \pm 5.20$ and $27.68 \pm 6.55$ respectively. Also it shows that highly statistical significant difference in all items between two groups $\mathrm{p}<0.000$.

Table 7. Correlation between student's satisfaction and Demographic characteristics, learning needs and academic achievement of two groups

\begin{tabular}{|c|c|c|c|c|}
\hline \multirow{2}{*}{ Items } & \multicolumn{2}{|c|}{ satisfaction of Lecture group $n=(200)$} & \multicolumn{2}{|c|}{ satisfaction of blended learning group $n=(191)$} \\
\hline & $\mathrm{R}$ & p- value & $\mathrm{R}$ & p-value \\
\hline Academic achievement & 0.230 & 0.001 & 0.212 & 0.003 \\
\hline Age & 0.023 & 0.741 & 0.095 & 0.189 \\
\hline Sex & $-0.117-$ & 0.100 & $-0.063-$ & 0.387 \\
\hline Residence place & 0.060 & 0.397 & -0.1380 & 0.058 \\
\hline Study course before & $-0.105-$ & 0.138 & 0.073 & 0.317 \\
\hline Learning needs & 0.037 & 0.606 & 0.157 & 0.030 \\
\hline
\end{tabular}

Table 7 shows that positive correlation between student's satisfaction and academic achievement in lecture and blended learning group sp $=0.001$ and 0.003 respectively, also it shows that positive correlation between student's satisfaction and learning difficulties in both groups $p=0.030$. Also This table shows that positive correlation between student's satisfaction and age in lecture group $\mathrm{P}=0.02$ while it shows that negative correlation between student's satisfaction and sex in booth groups.

\section{Discussion}

The discussion of this study covered three main parts;

- Demographic characteristics and Learning needs of lecture and blended learning groups in the first part.

- Assessment of academic achievement and students' satisfaction with lecture and blended learning groups in the second part.
- Correlation between student's satisfaction and Demographic characteristics, learning needs and academic achievement of two groups in the third part.

\subsection{Aim}

The aim of this study was to examine the effect of blended learning on newly nursing student's outcomes both academic achievement and student's satisfaction regarding new trends in nursing subject at Ain Shams University.

\subsection{Hypothesis}

It was hypothesized that the students who will be exposed to blended learning (Study group) will have improved outcomes booth academic achievement and student's satisfaction compared to the students in the control group who will be exposed to lecture regarding new trends in nursing subject 
Blended learning makes an important advancement to learning practice. It is an innovative learning practice since it adopts multiple learning methods and combines both traditional and online learning activities. Other than that, blended learning method continuously changes the ways of learning method and technological infrastructure [32].

\subsection{First Part}

The result of this study shows that there were no statistical significant differences between two groups regarding demographic characteristics; this might be related to the similar stage of age in the university studying. This finding was in agreement with Sherman et al [33] who found that male/female ratios were comparable in blended and lecture learning groups. Also Sheen et al [34] found that there was no significant difference with participants' age, gender, education, nursing experience, or computer learning experience.

The result of this study shows that the minority of lecture and blended learning groups had language's skills difficulties, less than half of them had computer's skills difficulties, and more than half of them had internet's skills difficulties. The rationale of the previous finding may be due to the age of the participants whereas, younger students had difficulties with online courses. So it is important that the students have the necessary computer skills as they may meet different e-learning systems throughout their careers. This finding was contradicted with HSU and HSIEH [35] who found that more than half of students always using e-mails and internet. While this finding was in agreement with Jokinen and Mikkonen [36] who found that the group included students whose skills were very good, and on the other, some students' skills were very poor. Also Abrami et al [37] found that blearning (blended) environment, making it more realistic according to the students' learning needs. In this way, the students could be involved in an active and engaging learning process during the courses.

The result of this study shows that minority of lecture and blended learning groups preferred e-learning, while most of lecture and blended learning groups preferred both lecture and e-learning together with no statistical significant differences between two groups. Ruiz et al. [9] argued that learners would benefit more from a blended learning model, which incorporates traditional-style classroom lectures with e-learning element than from a sudden switch to e-learning. This finding was contradicted with HSU and HSIEH [35] who stated that nursing students are generally more comfortable with traditionalstyle teaching where the teacher takes control of pretty much everything in the classroom, and they have a hard time making the switch to blended learning where they have to play a more active role in the classroom. In addition Twigg [38] who asserted that restricted access to computing facilities can be a major obstacle to successful implementation of the supplemental model of blended or e-learning.

\subsection{Second Part}

Regarding academic achievement, the result of this study shows that there was improvement regarding satisfactory achievement and decrease in the percent of poor and very poor in the academic achievement of blended learning group with no statistical difference between two groups. This minimal improvement may be due to the inability of the students in the study group to go to Internet cafes especially those who were residents in rural area and represent nearly one thirds of the studied sample.

Previous finding was in agreement with Yukie and Yoichiro [39] who found that students who attended the blended e-learning classes apparently thought that they had fundamentally achieved the learning objective. This finding also was in agreement with Wakefield et al [40] who found that no significant differences in posttest scores associated with participants' academic achievement. Also Colesca et al [41] found that blended learning was found to have contributed to learners' learning outcome by facilitating their met cognitive development and selfregulatory develop.

In a similar study, Pereira et al. [42] found that introduction of blended learning strategies had resulted in improved learning performance in terms of higher examination turnout, better grades and better exam pass rate among a group of freshmen biology majors taking the course 'human anatomy.' Also Schaber et al. [43] added that proved that both classroom and blended learning formats are effective in enhancing learner's perceived understanding of affective content, although blended learning was proved more effective than classroom learning.

Regarding academic achievement, the result of this study was contradicted with Zhigang [44] who found that Students had a slightly poorer academic achievement in blended learning environment. While Crawford et al [45] found that The nurses who participated in the blended learning course showed an increase in their knowledge in seven domains of knowledge. Also HSU and HSIEH [35] found that students who spent $<220$ min on the internet achieving more desirable learning outcome. Henderson [46] also found that adopting a blended approach to learning and teaching can have an opportunity to construct a meaningful learning experience and engage in a fundamental course to helping produce knowledgeable critical thinkers who capable of implementing evidence into their practice.

Regarding students' satisfaction the result of this study shows that less than half of lecture group was satisfied with this course while more than half of blended learning group were satisfied with this course with highly statistical significant difference in most items between two groups regarding students' satisfaction. The result of this study was contradicted with Gagnon et al [14] who found that there was no significant difference between groups regarding course's satisfaction (the Control group was slightly more satisfied, but not significantly).

Also Abou Naaj et al [47] stated that Student satisfaction in blended learning is important because it can impact motivation and, therefore, student success and completion rates. Measurement of satisfaction is also valuable to institutions because it can be used to evaluate courses and programs and, to a certain degree, to predict student attrition rates. Also authors added that analysis of data from survey forms has suggested that while blended learning continues to be regarded by most students as less effective, students still preferred face-to-face courses even 
though they were satisfied with their grades and performance in blended learning courses. Male students tended to be more satisfied with blended learning than their female counterparts.

Regarding student's satisfaction with teaching method, the result of this study shows that less than half of a lecture group was satisfied with teaching method while nearly two-thirds of blended learning group were satisfied with teaching method with highly statistical significant difference in most items between two groups regarding student's satisfaction with teaching method. The result of this study was in agreement with Sherman et al [33] who found that satisfaction with the method of education was discussed with focus group participants, blended learning participants responded very positively, indicating that the format was beneficial allowing for self-pacing and flexibility, interaction, and repeated access to information. The discussion sessions were considered valuable for clarification and to answer questions. Responses from lecture learners were also positive but less detailed than those of blended learners. Also Bates and Sangrà [48] found that blended learning achieve better learning outcomes and higher levels of satisfaction.

\subsection{Third part}

The result of this study shows that positive correlation between student's satisfaction and academic achievement in lecture and blended learning groups; also it shows that positive correlation between student's satisfaction and learning difficulties in both groups. Also this table shows that positive correlation between student's satisfaction and age in lecture group while it shows that negative correlation between student's satisfaction and sex in both groups.

This results were in accordance with Melton et al. [49] who compared a group of students' learning achievement and satisfaction with blended learning course delivery and traditional face to-face classroom teaching in a general health course. The result revealed that the students earned significantly higher grades and displayed higher satisfaction levels under a blended learning environment.

The result of this study was contradicted with Reime et al [50] who found that younger students did significantly better than older students in thee-learning group and women did better than men in the lecture group. Also Reime et al [50] found that it is important that the students have the necessary skills as they may meet different elearning systems throughout their careers. Also D'Souza et al [51] in other study found that the outcomes such as academic achievement measures are influenced by inputs or student characteristics such as gender, age.

\section{Conclusion}

In summary the result of this study support the hypothesis of this study in which blended learning improve newly nursing students' outcomes both academic achievement and student's satisfaction than lecture regarding new trend in nursing subject at Ain Shams University.

There was improvement regarding satisfactory level of achievement and decrease in the percent of poor and very poor of blended learning group with no statistical difference between two groups.

There was improvement in student's satisfaction of blended learning group regarding the course and teaching method with highly statistical significant difference between two groups.

\section{Recommendations}

Blended learning can be used to facilitate nursing education, more researches done to determine durability rate of the information of this methods.

\section{References}

[1] Billings, D.M. \& Halstead, J.A. Teaching in nursing: A guide for faculty, $4^{\text {th }}$ ed. 2011, St. Louis, MO: Saunders Elsevier.

[2] Li Z., Tsai M., Tao J., Lorentz C. Switching to blended learning: The impact on students' academic performance. Journal of Nursing Education and Practice, 2014, Vol. 4, No. 3. 245-251.

[3] Thornock S. B. Proactive solutions to academic dishonesty. Open Journal of Nursing, 2013, 3, 552-556 OJN.

[4] Sharma N., and Kaur A. Factors associated with stress among nursing students. Nursing and Midwifery Research Journal, January 2011, Vol-7, No. 1

[5] Meehan-Andrews, T.A. Teaching mode efficiency and learning preferences of first year nursing students. Nurse Education Today. 2009, 29, 24-32.

[6] Enlow, M., Shanks, L., Guhde, J. Perkins, M. Incorporating interprofessional communication skills (IS-BARR) into an undergraduate nursing curriculum. Nurse Educator. 2010, 35, 176180.

[7] Taylor, L.A., Hudson, K., Vazzano, J., Naumann, P. and Neal, M. The electronic health record meets baccalaureate nursing curriculum: Stories from the battlefield. Nurse Leader. 2010, 8, 40-44.

[8] Bodie G.D., Fitch-Hauser M.F. \& Powers W.G. Chunking, priming, and active learning: toward an innovative and blended approach to teaching communication related skills. Interactive Learning Environments. 2006, 14, 119-135.

[9] Ruiz J.G., Mintzer M.J. \& Leipzig R.M. The impact of e-learning in medical education. Academic Medicine. 2006, 81 (3), 207-212.

[10] Holenko $\mathrm{M}$ and Hoic-Bozic N. Using online discussions in a blended learning course. Ijet 2008; 2 (2): 18-23.

[11] Pereira J, Pleguezuelos E, Meri A, et al. Effectiveness of using blended learning strategies for teaching and learning human anatomy. Med Educ 2007; 41: 189-95.

[12] Precel, K., Eshet-Alkalai, Y., \&Alberton, Y.. Pedagogical and Design Aspects of a Blended Learning Course. International Review of Research in Open and Distance Learning. April 2009, 10 (2), 1-16.

[13] Søilen, K. S.. Increased interactivity to reduce drop-out rate on distance learning programs. Blekinge Institute of Technology. Sweden, (2007) Retrieved May 19, 2011, from http://www.bth.se/fou/Forskinfo.nsf/Sok/2dd7509484a76fd2c1257 2720046d5f7/\$ file/EDEN\%20conference\%20soilen.pdf

[14] Gagnon M. P., Gagnon J., Desmartis M., and Njoya M. The Impact of Blended Teaching on Knowledge, Satisfaction, and Self-Directed Learning in Nursing Undergraduates: ARandomized, Controlled Trial, Nursing Education Perspectives, November 2013. Vol. 34, No. 6, pp. 377-382.

[15] Art, B., \& Lisa, E. Designing and delivering effective online nursing courses with evolve electronic classroom. Journal of Computer Information Nursing, 2008. 26 (5), 54-60.

[16] Abdelaziz M., Kamel S.S., Karam O., Abdelrahman A. Evaluation of E-learning program versus traditional lecture instruction for undergraduate nursing students in a faculty of nursing, Teaching and Learning in Nursing, 6 (2), 2011, 50-58.

[17] Allen, I. E., Seaman, J., \& Garrett, R.. What is blended learning. Blending in: The extent and promise of blended education in the United States, 2007, 1-29. Retrieved from http://www.sloanc.org/publications/survey/pdf/Blending_In.pdf 
[18] Dziuban, C. D., Hartman, J. L., \&Moskal, P. D. Blended learning Educause Center for Applied Research, 2004 (7), 4. Retrieved from http://net.educause.edu/ir/library/pdf/ERB0407.pdf

[19] Huett, J.B., Kalinowski, K.E., Moller, L., \&Huett, K.C. Improving the motivation and retention of online students through the use of ARCSbased e-mails. The American Journal of Distance Education, 2008. 22, pp. 159-176.

[20] Murray, D. Comparison of academic achievement for arn-bsn program course using online and traditional face-to-face classroom learning environment delivery methods. (Order No. 1551952, Morehead State University). ProQuest Dissertations and Theses, 2014. 85.

[21] Chen, N., Lin, K., \&Kinshuk. Analysing users' satisfaction with elearning using a negative critical incidents approach. Innovations in Education and Teaching International, May, 2008. 45 (2), 115126.

[22] Chiu, C., Sun, S., Sun, P., Ju, T. L. An empirical analysis of the antecedents of Web-based learning continuance. Computers and Education, December, 2007. 49 (4), 1224-1245.

[23] Johnson, N., List-Ivankovic, J., Eboh, W. O., Ireland, J., Adams, D., Mowatt, E., et al.. Research and evidence based practice: Using a blended approach to teaching and learning in undergraduate nurse education. Nurse Education in Practice, 2010; 10 (1), 43-47.

[24] Ward, R., Moule, P. Supporting pre-registration students in practice: A review of current ICT use. Nurse Education Today, 2007. 27 (1), 60-67.

[25] Albarrak AI; "Designing E-Learning Systems in Medical Education: A Case Study”, International Journal of Excellence in Healthcare Management, 2010; 3 (1): 1-8.

[26] Gopal, T., Herron, S.S., Mohn, R.S., Hartsell, T., Jawor, J.M., and Blickenstaff, J.C., Effect of an interactive web-based instruction in the performance of undergraduate anatomy and physiology lab students. Computers \& Education, 2010; 55, pp. 500-512

[27] Ross, P.M., Tronson, D.A., and Ritchie, R.J., Increasing conceptual understanding of glycolysis and the Krebs cycle using role-play. Am Biol Teach, 2008. 70, pp. 163-169.

[28] Gerdprasert, G., Pruksacheva, T., Panijpan, P., and Ruenwongsa, P., Development of a web-based learning medium on mechanism of labour for nursing Students. Nurse Education Today, 2010. 30 (5), pp. 464-469

[29] Kumrow, D.E., Evidence-based strategies of graduate students to achieve success in a hybrid web-based course. Journal of Nursing Education, 2007; 46 (3), pp. 140-145.

[30] Limpach, A.L., Bazrafshan, P., Turner, P.D., and Monaghan, M.S., Effectiveness of human anatomy education for pharmacy students via the internet. American Journal of Pharmaceutical Education, 2008; 72 (6) Article 145 pp. 1-5

[31] Guerri-Guttenberg, R.A., Web-based method for motivating 18year old anatomy students. Medical Education, 2008; 42, p. 1119.

[32] Chou, A. Y. and Chou, D. C. (2011), Course Management Systems and Blended Learning: An Innovative Learning Approach. Decision Sciences Journal of Innovative Education, 9: 463-484.

[33] Sherman, H, L Comer, L Putnam, and H Freeman. "Blended Versus Lecture Learning: Outcomes for Staff Development." Journal for Nurses in Staff Development, 28 (4), 2012: 186-190.

[34] Sheen, S.H., Chang, W., Chen, H. Chao, H. \& Tseng, C. Elearning education program for registered nurses: The experience of a teaching medical center. Journal of Nursing Research, 2008; 16 (3), 195-200.
[35] HSU L.-L. \& HSIEH S.-I. Effects of a blended learning module on self reported learning performances in baccalaureate nursing students. Journal of Advanced Nursing 67 (11), 2435-2444.

[36] Jokinen P., Mikkonen I. Teachers' experiences of teaching in a blended learning environment. Nurse Education in Practice. 2013; 13 ; $524-528$

[37] Abrami, P., Bernard, R., Bures, E., Borokhovski, E., \&Tamim, R. Interaction in distance education and online learning: using evidence and theory to improve practice. Journal of Computing in Higher Education, 2011; 23 (2-3), 82-103.

[38] Twigg, C.A., New models for online learning improving learning and reducing costs, EDUCAUSE review, September/October 2003; 23-36. http://www.educause.edu/ir/library/pdf/erm0352.pdf

[39] Yukie M, Yoichiro S. Development of E-lcarning for Problem solving Approach of Nursing Students. Studies in health Technology and Informatics 2006; 122: 919.

[40] Wakefield A. Carlisle C. Hall A. and Attree M. The expectations and experiences of blended learning approaches to patient safety education, Nurse Education in Practice. 2008; 8, 54-61

[41] Colesca, S. E., Dobrica, L., \&Alpopi, C. Students outcomes and perceptions in a blended learning format. Metalurgia International. 2009; 8, 222-229.

[42] Pereira J. Pleguezuelos E. Meri A. Molina-Ros A. Molina-Tomas M.C. \& Masdeu C. Effectiveness of using blended learning strategies for teaching and learning human anatomy. Medical Education. 2007; 41, 189-195.

[43] Schaber P., Wilcox K.J., Whiteside A., Marsh L. \& Brooks C. Design learning environments to foster affective learning: comparison of classroom to blended learning. Interactional Journal for the Scholarship of Teaching and Learning. 2010; 4 (2), 1-18.

[44] Zhigang Li, Ming-Hsiu Tsai, Jinyuan Tao, Chris Lorentz. Switching to blended learning: The impact on students' academic performance, Journal of Nursing Education and Practice, 2014, Vol. 4, No. 3.

[45] Crawford J. Brudnoy L. Soong T. and Graham T. Patient Navigation in Oncology Nursing:An Innovative Blended Learning Model, J Contin EducNurs, 2013; 44 (10): 461-469.

[46] Henderson G. The situation of constructing a blended learning approach to meet with student diversity in nursing; an insight into the literature. Proceedings of INTED 2010 Conference. 8-10 March 2010, Valencia, Spain. 003643-003649.

[47] Abou Naaj M. Nachouki M. and Ankit A. Evaluating Student Satisfaction with Blended Learning in a Gender-Segregated Environment. Journal of Information Technology Education: Research. Volume 11, 2012.

[48] Bates, A.W., \&Sangrà, A. Recent developments in technology and education. In A. W. Bates \& A. Sangrà (Eds.), Managing Technology in Higher Education: Strategies for Transforming Teaching and Learning (2011 a). (pp. 25-51). San Francisco, CA: Jossey-Bass.

[49] Melton, B., Graf, H., Chopak-Foss J. Achievement and Satisfaction in Blended Learning versus Traditional General Health Course Designs. International Journal for the Scholarship of Teaching and Learning, 2009; 3 (1), 1-13.

[50] Reime M., Harris A., Aksnes J. \&Mikkelsen J. The most successful method in teaching nursing students infection control-elearning or lecture? Nurse Education Today. 2008; 28 (7), 798-806.

[51] D’Souza M. S. Isac C. Venkatesaperumal R. Nairy K. S. Amirtharaj A. Exploring nursing student engagement in the learning environment for improved learning outcomes, Clinical Nursing Studies, 2014, Vol. 2, No. 1. 